Article

\title{
Identification and Active Evaluation of Antioxidant Peptides from Protein Hydrolysates of Skipjack Tuna (Katsuwonus pelamis) Head
}

\author{
Lun Zhang ${ }^{1}$, Guo-Xu Zhao ${ }^{2}$, Yu-Qin Zhao ${ }^{1}$, Yi-Ting Qiu ${ }^{1}$, Chang-Feng Chi ${ }^{2, *}$ (1) \\ and Bin Wang ${ }^{1, *}$ \\ 1 Zhejiang Provincial Engineering Technology Research Center of Marine Biomedical Products, School of Food \\ and Pharmacy, Zhejiang Ocean University, Zhoushan 316022, China \\ 2 National and Provincial Joint Laboratory of Exploration and Utilization of Marine Aquatic Genetic \\ Resources, National Engineering Research Center of Marine Facilities Aquaculture, School of Marine Science \\ and Technology, Zhejiang Ocean University, Zhoushan 316022, China \\ * Correspondence: chichangfeng@hotmail.com (C.-F.C.); wangbin@zjou.edu.cn (B.W.); \\ Tel./Fax: +86-580-255-4818 (C.-F.C.); +86-580-255-4781 (B.W.)
}

Received: 31 July 2019; Accepted: 16 August 2019; Published: 19 August 2019

\begin{abstract}
For the full use of fish by-products to produce antioxidant peptides, skipjack tuna (Katsuwonus pelamis) heads generated during can processing were defatted and hydrolyzed using the in vitro gastrointestinal (GI) digestion (pepsin-trypsin system) method and six antioxidant peptides (P1 to P6) were purified from the head hydrolysate (KPH) using ultrafiltration and serial chromatography methods. Six isolated peptides (P1 to P6) were identified as Val-Glu-Glu (VEE, P1), Trp-Met-Phe-Asp-Trp (WMFDW, P2), Asp-Ala-Gly-Pro-Tyr-Gly-Pro-Ile (DAGPYGPI, P3), Trp-Met-Gly-Pro-Tyr (WMGPY, P4), Glu-Arg-Gly-Pro-Leu-Gly-Pro-His (ERGPLGPH, P5), and Glu-Met-Gly-Pro-Ala (EMGPA, P6), respectively, using a protein sequencer and electrospray ionization-mass spectrometer. Among skipjack tuna head hydrolysates, fractions, and six isolated peptides (P1 to P6), WMFDW (P2), WMGPY (P4), and EMGPA (P6) showed the highest radical scavenging activities on 2,2-diphenyl-1-picrylhydrazyl (DPPH) (EC50 values of 0.31, 0.33, and $0.46 \mathrm{mg} / \mathrm{mL}$ for WMFDW, WMGPY, and EMGPA, respectively), hydroxyl (EC 50 values of $0.30,0.43$, and $0.52 \mathrm{mg} / \mathrm{mL}$ for WMFDW, WMGPY, and EMGPA, respectively), and superoxide anion $\left(\mathrm{EC}_{50}\right.$ values of $0.56,0.38$, and $0.71 \mathrm{mg} / \mathrm{mL}$ for WMFDW, WMGPY, and EMGPA, respectively). Moreover, WMFDW, WMGPY, and EMGPA showed strong capability in reducing power and lipd peroxidation inhibition in the linoleic acid system. In addition, WMFDW, WMGPY, and EMGPA can retain strong antioxidant activity at temperatures lower than $60{ }^{\circ} \mathrm{C}$ and $\mathrm{pH}$ values ranged from 5 to 9 . The results showed that six isolated peptides (P1 to P6) from skipjack tuna heads, especially WMFDW, WMGPY, and EMGPA, might be applied in health care products acting as powerful antioxidant agents.
\end{abstract}

Keywords: skipjack tuna (Katsuwonus pelamis); head; peptide; antioxidant activity; stability

\section{Introduction}

Bioactive peptides generally range in molecular size from 2 to 20 amino acid residues and show a large number of potential physiologic functions within biological bodies, such as antioxidant, opioid, antihypertensive, immunomodulatory, antithrombotic, and antibacterial activities [1-4]. The identification, quantitation and activity evaluation of food-derived bioactive peptides are very important for the characterization of its production, biological value and benefits for consumer health [5,6]. In general, bioactive peptides can be produced during food manufacturing either by the spontaneous hydrolysis of food proteins with endogenous digestive enzymes, or by designing 
hydrolysis conditions with commercial proteases [7-9]. In addition, bioactive peptides can also be released during the gastrointestinal digestion of the ingested foods [10].

Presently, a large number of bioactive peptides has been produced from food proteins of different origins like milk, eggs, soya, fish, mollusk and meat [7,11-13]. Among them, antioxidant peptides (APs) derived from aquatics and their byproducts, such as the heads and viscera of sardinella [14], skin and viscera of cuttlefish [15], carcass and viscera of Nile tilapia [16], heads and skins of bluefin leatherjacket (Navodon septentrionalis) [6,12], and swim bladders and muscle of miiuy croaker (Miichthys miiuy) [8,17], have attracted much investigative and public interests because they can positively influence health in the body and have huge potential applied in functional and health products $[5,18]$. Two hexapeptides of WAFAPA and MYPGLA from the protein hydrolysate of blue-spotted stingray can protect DNA and proteins from oxidation and show stronger capability to restrain $\mathrm{H}_{2} \mathrm{O}_{2}$-induced lipid oxidation than carnosine [19]. The gelatin hydrolysate fraction of Nile tilapia skin (FSGHFs) (molecular weight $(\mathrm{MW})<1000 \mathrm{Da})$ can increase cell viability and membrane integrity, suppress reactive oxide species (ROS) production and epithelial barrier damage in $\mathrm{H}_{2} \mathrm{O}_{2}$-induced intestinal porcine epithelial cells (IPEC-J2) by stimulating the nuclear factor erythroid 2-related factor 2 (Nrf2) to increase the level of glutathione and the mRNA and protein expression of catalytic and modulatory subunits of $\gamma$-glutamyl cysteine ligase [20]. In addition, a pentapeptide of YGDEY from tilapia gelatin hydrolysates can inhibit ultraviolet B (UVB)-mediated skin photoaging by decreased MMP-1 (collagenase) and MMP-9 (gelatinase) expression, increase antioxidant factors superoxide dismutase (SOD) and glutathione (GSH) expression, and prevent DNA from oxidative damage [21]. Tao et al. reported that GAERP, GEREANVM, and AEVG can effectively scavenge free radicals and protect human liver cancer cell line (HepG2) from $\mathrm{H}_{2} \mathrm{O}_{2}$-induced oxidative damage through reducing the malondialdehyde (MDA) level and promoting the contents of glutathione reductase (GSH-Rx), SOD, glutathione peroxidase (GSH-Px), and catalase (CAT) [22]. The literature proved that seafood-derived APs have high antioxidant capability and can be applied in health care food to protect cells and organisms against oxidative stress.

As an epipelagic oceanic species, skipjack tuna (Katsuwonus pelamis) mainly live in tropical and subtropical seas with over 2 million metric tons of production every year in the Pacific Ocean [23]. In China, approximately 200,000 tons of tuna are processed every year and its byproducts accounted for approximately $50 \%$ of the raw material, including fish bones, head, scales, viscera and skins, are generated during tuna can processing [24]. Traditionally, these tune byproducts are processed into low-value fish flour utilized in animal feeds or dumped as harmful wastes [24]. In recent years, the production of bioactive molecules including collagen, gelatin, and bioactive peptides using tuna byproducts were studied as a promising means to increasing tuna value and lowering environmental pollution. Yu et al. prepared collagens from the spines and skulls of skipjack tuna and characterized them as type I collagen [24]. Shyni et al. prepared the skin gelatin of skipjack tuna with yield of $11.3 \%$ and analyzed its physical and chemical properties, such as MW, viscosity, odor, color, melting point, amino acid composition, and water-holding capacity [25]. GADIVA and GAEGFIF from the gelatin hydrolysate of skipjack tuna bone exhibited high inhibiting ability on lipid peroxidation and strong radical scavenging activities on 2,2-diphenyl-1-picrylhydrazyl (DPPH), hydroxyl, superoxide anion, and 2,2'-azino-bis-3-ethylbenzothiazoline-6-sulfonic acid (ABTS). They attributed the high activity of GADIVA and GAEGFIF to small MW and hydrophobic/aromatic amino acids [10]. Chi et al. prepared alcalase and neutrase hydrolysates of skipjack tuna dark muscle and illuminated the effects of amino acid compositions, MW, and AP profiles on their protective capacities of lipid peroxidation [23]. However, no literature on APs from skipjack tuna head was found. Therefore, the objectives of this investigate were to prepare APs from the head hydrolysate of skipjack tuna, identify the MWs and amino acid sequences of isolated APs, and assess their in vitro antioxidant activities at the end of this study. 


\section{Materials and Methods}

\subsection{Materials}

Skipjack tuna (K. pelamis) heads were provided by Ningbo Todayfood Co. Ltd. (China). Diethylethanolamine (DEAE)-52 cellulose and Sephadex G-25 were purchased from Shanghai Source Poly Biological Technology Co., Ltd. (China). Trifluoroacetic acid (TFA) and Acetonitrile (ACN) of liquid chromatogram grade were purchased from Thermo Fisher Scientific Co., Ltd. (Shanghai, China). DPPH and GSH of pharmaceutical secondary standard were purchased from Sigma-Aldrich Trading Co., Ltd. (Shanghai, China). Val-Glu-Glu (VEE, P1), Trp-Met-Phe-Asp-Trp (WMFDW, P2), Asp-Ala-Gly-Pro-Tyr-Gly-Pro-Ile (DAGPYGPI, P3), Trp-Met-Gly-Pro-Tyr (WMGPY, P4), Glu-Arg-Gly-Pro-Leu-Gly-Pro-His (ERGPLGPH, P5), and Glu-Met- Gly-Pro-Ala (EMGPA, P6) were synthesized in China Peptides Co. (Suzhou, China).

\subsection{Preparation of the Protein Hydrolysate (KPH) of Kipjack Tuna Heads}

Skipjack tuna heads were thawed, cleaned with tap water, minced, and defatted with the previously mentioned method [6]. In brief, the homogenate was mixed with isopropanol at a ratio of 1:5 (w/v) and left to stand at $30 \pm 2{ }^{\circ} \mathrm{C}$ with continuous agitation, and the isopropanol was changed after $2.0 \mathrm{~h}$. Finally, the solution was centrifuged at $6000 \mathrm{~g}$ for $15 \mathrm{~min}$, and the precipitate was dried at $35 \pm 2{ }^{\circ} \mathrm{C}$.

The protein hydrolysate $(\mathrm{KPH})$ of skipjack tuna heads was prepared using the in vitro gastrointestinal (GI) digestion method [10]. Briefly, the defatted powders dispersed in distilled water (DW) $(\mathrm{pH} \mathrm{1.5,1 \% )} \mathrm{were} \mathrm{firstly} \mathrm{hydrolyzed} \mathrm{by} \mathrm{pepsin} \mathrm{with} \mathrm{a} \mathrm{protease} \mathrm{dosage} \mathrm{of} 1 \mathrm{~g}$ pepsin/100 $\mathrm{g}$ defatted powder under the conditions of $37.0 \pm 2{ }^{\circ} \mathrm{C}$ and $\mathrm{pH} 1.5$. Two hours later, the $\mathrm{pH}$ of the degraded solution was adjusted to 7.0 using 1.0 $\mathrm{M} \mathrm{NaOH}$ solution and further hydrolyzed using trypsin with a protease dosage of $1 \mathrm{~g}$ trypsin/100 $\mathrm{g}$ defatted powder. After $2 \mathrm{~h}$, the temperature of the solution was increased to $95 \pm 2{ }^{\circ} \mathrm{C}$ and kept for $10 \mathrm{~min}$. Finally, the solution was centrifuged at $9000 \mathrm{~g}$ for $10 \mathrm{~min}$ at $4{ }^{\circ} \mathrm{C}$ and the supernatant $(\mathrm{KPH})$ was lyophilized and stored in a $-20{ }^{\circ} \mathrm{C}$ freezer.

The concentrations of $\mathrm{KPH}$ and its fractions were measured by the method described by Bradford [26] and represented as $\mathrm{mg}$ protein/mL. The degree of the hydrolysis (DH) analysis of protein hydrolysates was performed according to the method described by Yang et al. [13].

\subsection{Preparation of APs from $K P H$}

\subsubsection{Ultrafiltration}

$\mathrm{KPH}$ was ultra-filtrated using MW cut-off (MWCO) membranes of 3, 5 and $10 \mathrm{kDa}$, and four resulting fractions, defined as UF-1 (MW < 3 kDa), UF-2 (3-5 kDa), UF-3 (5-10 kDa), and UF-4 (MW > $10 \mathrm{kDa})$, were prepared and lyophilized.

\subsubsection{Separation of APs by Chromatography Methods}

The separation process of APs from UF-1 was performed according to the method described by Yang et al. [13]. Briefly, UF-1 (5 mL, $40.0 \mathrm{mg}$ protein/mL) was injected into a pre-equilibrated DEAE-52 cellulose column $(2.6 \mathrm{~cm} \times 120 \mathrm{~cm})$ and eluted with $150 \mathrm{~mL} \mathrm{DW}$ and $0.1,0.5$, and $1.0 \mathrm{M} \mathrm{NaCl}$ solution at a flow rate of $1.0 \mathrm{~mL} / \mathrm{min}$. Each eluted fraction $(5 \mathrm{~mL})$ was collected and monitored at $214 \mathrm{~nm}$. Finally, six fractions (defined as AC-1 to AC-6) were prepared on the peaks of the 214-nm chromatographic curve, and $5 \mathrm{~mL}$ AC-4 solution (20.0 mg protein $/ \mathrm{mL})$ was added into a Sephadex G-25 column $(2.6 \mathrm{~cm}$ $\times 160 \mathrm{~cm}$ ) and separated with a flow rate of $0.8 \mathrm{~mL} / \mathrm{min}$. Three active factions (defined as GC-1, GC-2, and GC-3) were prepared on the chromatographic curve on the 214-nm absorbance of each eluate (3 mL). Finally, GC-3 (20 $\mu \mathrm{L}, 10.0 \mathrm{mg}$ protein/mL) was further purified by a High-performance liquid chromatography (HPLC) column of Zorbax, SB C-18 (4.6 mm $\times 250 \mathrm{~mm})$ on an Agilent 1260 system (Agilent Ltd., Santa Rosa, CA, USA). GC-3 was eluted with ACN solution containing $0.1 \%$ TFA at 
$1.0 \mathrm{~mL} / \mathrm{min}$ and the ACN concentration increased from 0 to $50 \%$ in $25 \mathrm{~min}$ in a linear gradient manner. Six APs (P1 to P6) were prepared on the HPLC chromatographic peaks at $214 \mathrm{~nm}$.

\subsection{Analysis of Amino Acid Sequence and MW}

The amino acid sequences of six APs (P1 to P6) were analyzed using a protein sequencer of Applied Biosystems 494 (Applied Biosystems Inc, Foster City, CA, USA). The MWs of six APs (P1 to P6) were determined by a quadrupole time-of-flight mass spectrometer (MS) coupled with an electrospray ionization (ESI) source, respectively.

\subsection{Antioxidant Activity}

The radical scavenging assays of six APs (P1 to P6) were tested on the method described by Yang et al. [13]. The half elimination ratio $\left(\mathrm{EC}_{50}\right)$ was used to express the radical scavenging capability of six APs and defined as the concentration of a sample that caused a $50 \%$ decrease in the initial radical concentration. The assays of lipid peroxidation inhibition and reducing power were determined by the method described by He et al. [17].

\subsection{Stability Properties}

The stability of APs (P2, P4, and P6) was measured according to the previous method [13]. The thermostability of APs was determined using a water bath for $0.5 \mathrm{~h}$ and the temperature was set as $20,40,60,80$, or $100^{\circ} \mathrm{C}$. The influences of $\mathrm{pH}$ treatments at $\mathrm{pH}$ values of $3,5,7,9$, or 11 were used to evaluate the $\mathrm{pH}$ stability of APs (P2, P4, and P6) at $25^{\circ} \mathrm{C}$ for $2.5 \mathrm{~h}$. The $\mathrm{EC}_{50}$ values of APs (P2, P4, and P6) on hydroxyl radical were used as an index and tested using the methods described in Section 2.5 .

\subsection{Statistical Analysis}

The data are expressed as the mean \pm standard deviation (SD, $n=3)$. An ANOVA test was used to analyze the differences in data from different groups, and a $p$-value of less than 0.05 was considered statistically significant.

\section{Results and Discussion}

\subsection{Preparation of the Protein Hydrolysate (KPH) of Kipjack Tuna Heads}

According to the chemical composition analysis, the major components in skipjack tuna heads were moisture, protein, fat, and ash, with contents of $67.1 \pm 3.4,14.6 \pm 0.86,10.2 \pm 0.25$, and $6.2 \pm$ $0.93 \mathrm{~g} / 100 \mathrm{~g}$, respectively, on the wet weight basis. The data demonstrated that skipjack tuna heads were suitable for the production of bioactive peptides due to their high protein content.

Proteins of skipjack tuna heads were hydrolyzed by the in vitro GI digestion system, and the prepared hydrolysate $(\mathrm{KPH})$ with a $\mathrm{DH}$ of $25.76 \pm 1.68 \%$ can effectively scavenge DPPH radical with an $\mathrm{EC}_{50}$ value of $5.36 \mathrm{mg}$ protein/mL. The $\mathrm{EC}_{50}$ value was lower than those of protein hydrolysates from skate cartilage (13.13 mg protein/mL) [3] and bluefin leatherjacket skin (5.23 $\mathrm{mg}$ protein/mL) [12], but higher than those of protein hydrolysates from Tergillarca granosa muscle (3.55 $\mathrm{mg}$ protein $/ \mathrm{mL}$ ) [13], tilapia skin $(3.66 \mathrm{mg} / \mathrm{mL})$ [16], thornback ray $(1.98 \mathrm{mg} / \mathrm{mL})$ [27], and salmon pectoral fin $(1.63 \mathrm{mg} / \mathrm{mL})$ [28]. Therefore, the results indicated that the in vitro GI digestion model was effective in preparing bioactive peptides of skipjack tuna heads.

\subsection{Purification of APs from $\mathrm{KPH}$}

\subsubsection{Ultrafiltration}

KPH was divided by ultrafiltration with MWCO membranes of 3,5, and $10 \mathrm{kDa}$, and four fractions, namely, UF-1 (MW < 3 kDa), UF-2 (3-5 kDa), UF-3 (5-10 kDa), and UF-4 (MW > $10 \mathrm{kDa}$ ), were prepared, and their scavenging activity on the DPPH radical is shown in Figure 1 . The $\mathrm{EC}_{50}$ value of UF-1 was 
$3.24 \mathrm{mg}$ protein/mL, which was significantly stronger than those of $\mathrm{KPH}$ (5.36 mg protein/mL), and other three fractions $\left(\mathrm{EC}_{50}\right.$ value of $4.68,8.74$, and $11.20 \mathrm{mg}$ protein/mL for UF-2, UF-3, and UF-4, respectively) $(p<0.05)$. KPH consisted of a wide variety of APs with different molecular sizes. Li et al. reported that hydrolysate fractions with a lower MW were more accessible to free radicals and showed high radical scavenging activity [29]. Therefore, UF-1 was rich in low MW APs and selected for the subsequent chromatographic separation.

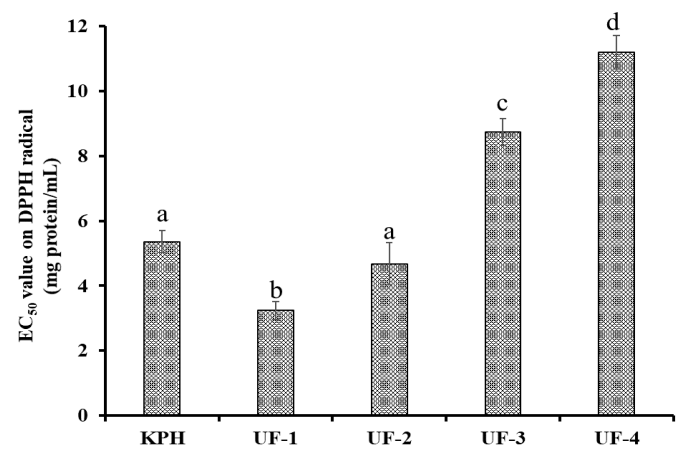

Figure 1. The half elimination ratio $\left(\mathrm{EC}_{50}\right)$ of the hydrolysate $(\mathrm{KPH})$ and its four active fractions (defined as UF-1 to UF-4) by ultrafiltration on the 2,2-diphenyl-1-picrylhydrazyl (DPPH) radical. The data are presented as the mean $\pm \mathrm{SD}(n=3)$. ${ }^{\mathrm{a}-\mathrm{d}}$ The same superscripts indicate no significant difference $(p>0.05)$.

\subsubsection{Anion-Exchange Chromatography}

Figure 2A showed the anion-exchange chromatographic chart of six fractions (AC-1 to AC-6) from UF-1. According to their adsorption capacity with the DEAE-52 cellulose, AC-1, AC-2 and AC-3, AC-4 and AC-5, and AC-6 were gradually eluted out by an eluent of DW, $0.1 \mathrm{NaCl}$ solution, $0.5 \mathrm{NaCl}$ solution, and $1.0 \mathrm{M} \mathrm{NaCl}$ solution, respectively.
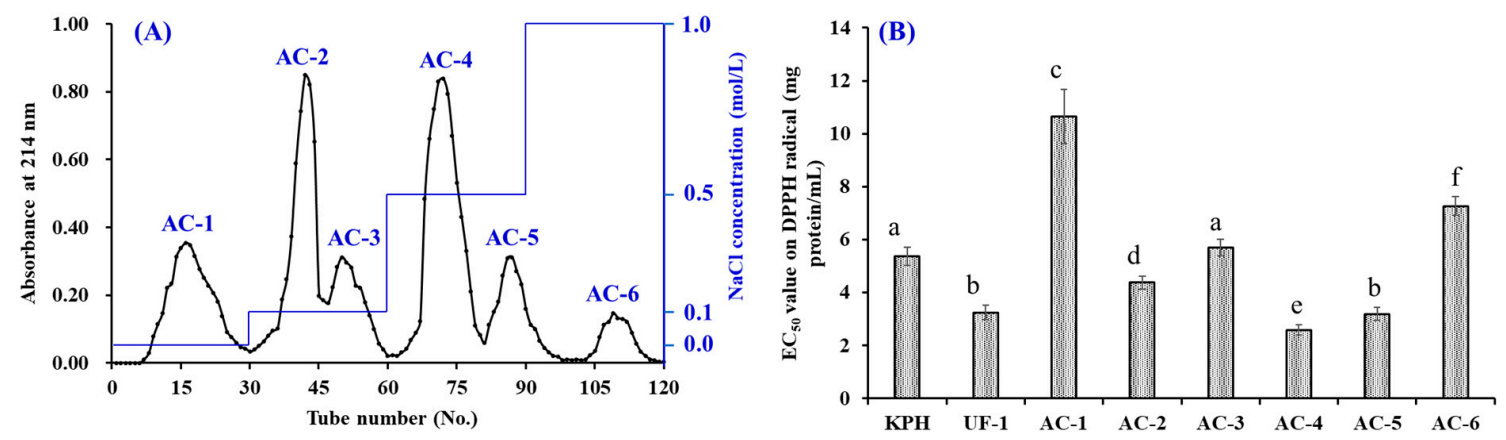

Figure 2. Elution diagram of UF-I in the diethylethanolamine (DEAE)-52 cellulose column of (A) and $\mathrm{EC}_{50}$ values of UF-I and its active fractions (defined as AC-1 to AC-6) on the DPPH radical (B). The data are presented as the mean $\pm \mathrm{SD}(n=3)$. ${ }^{\mathrm{a}-\mathrm{f}}$ The same superscripts indicate no significant difference $(p>0.05)$.

The data in Figure $2 \mathrm{~B}$ suggested that the $\mathrm{EC}_{50}$ value of $\mathrm{AC}-4(2.58 \mathrm{mg}$ protein $/ \mathrm{mL})$ was significantly less than those of UF-I (3.24 mg protein/mL) and other five fractions ( $\mathrm{EC}_{50}$ values of 10.65, 4.37, 5.69, 3.18 , and $7.26 \mathrm{mg}$ protein/mL for AC-1, AC-2, AC-3, AC-5, and AC-6, respectively) $(p<0.05)$. Amino acid residues in bioactive peptides with the acidic and hydrophobic groups can be easily adsorbed to the anion-exchange resin (Q Sepharose FF, DEAE, DEAE-52 cellulose and XK 260) and separated from other peptides [6,30]. Moreover, amino acid residues with acidic and/or hydrophobic groups, such as Glu, Met, His, Asp and Pro, are recognized as one of the vital factors for the activity of APs [3,31]. Thus, AC-4 isolated should contain APs with high potential activity and was selected for the following experiment. 


\subsubsection{Gel Filtration Chromatography (GFC)}

Figure 3A indicated that AC-4 was separated into three active components (GC-1 to GC-3) by the Sephadex G-25 column. The DPPH radical scavenging assay showed that GC-3 with an EC 50 value of $1.65 \mathrm{mg}$ protein $/ \mathrm{mL}$ had a significantly stronger activity than AC-4 $(2.58 \mathrm{mg}$ protein $/ \mathrm{mL})$, and the other two active components (EC 50 values of 5.73 and $3.49 \mathrm{mg}$ protein/mL for GC-1 and GC-2, respectively) $(p<0.05)$.
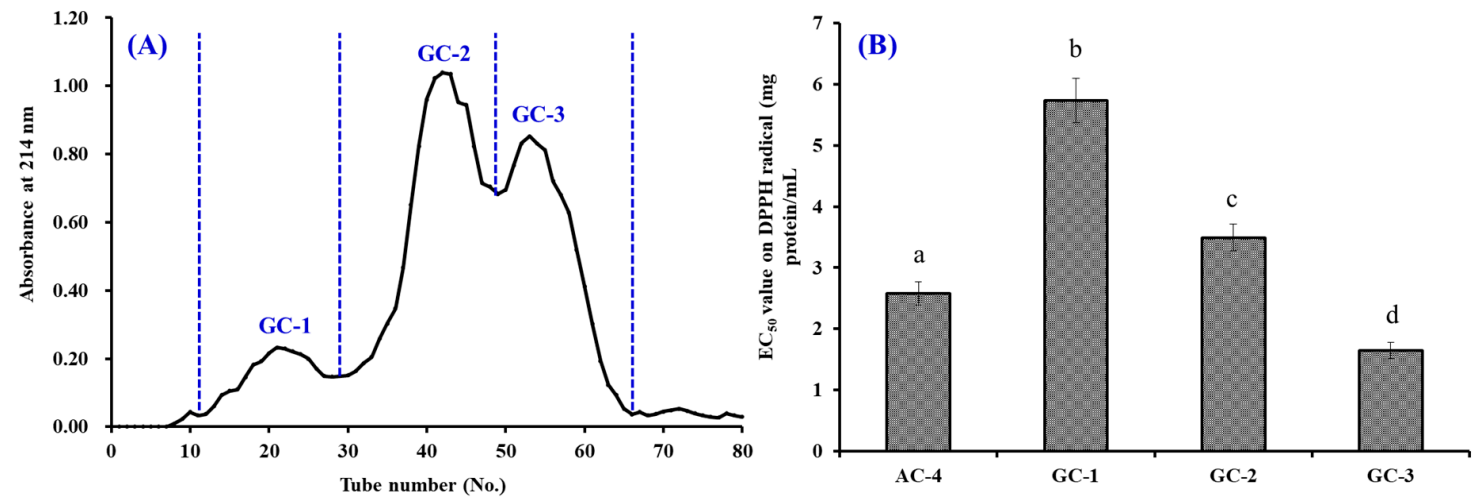

Figure 3. Elution diagram of AC-4 in the Sephadex G-25 column of (A) and EC 50 value of AC-4 and its three active fractions (defined as GC-1 to GC-3) on the DPPH radical (B). The data are presented as the mean $\pm \operatorname{SD}(n=3)$. ${ }^{a-d}$ The same superscripts indicate no significant difference $(p>0.05)$.

Gel filtration has been used for separating bioactive peptides from protein hydrolysates of aquatic byproducts, such as salmon [28], sardinelle [14], cartilaginous fish [32-34], blue mussel [31], skipjack tuna [23], miiuy croaker [8], and cuttlefish [15]. The presented results were in agreement with the report by $\mathrm{Li}$ et al. and Pan et al. that peptide components with a low-average MW possess stronger antioxidant activities than their larger counterparts [29,35]. Therefore, GC-3 was suitable for the following purification process.

\subsubsection{Purification of APs from GC-3 by Reversed-Phase HPLC (RP-HPLC)}

Finally, GC-3 was purified using a Zorbax C-18 column on an Agilent 1260 HPLC system and the elution profile is shown in Figure 4. The eluted APs were collected on their chromatographic peaks. In the end, six APs from GC-3, with a retention time (RT) of $9.05 \mathrm{~min}$ (P1), $11.36 \mathrm{~min}$ (P2), $12.63 \mathrm{~min}$ (P3), $13.25 \mathrm{~min}$ (P4), $16.78 \mathrm{~min}(\mathrm{P} 5)$, and $17.22 \mathrm{~min}$ (P6), were prepared for molecular structural identification and bioactivity analysis.

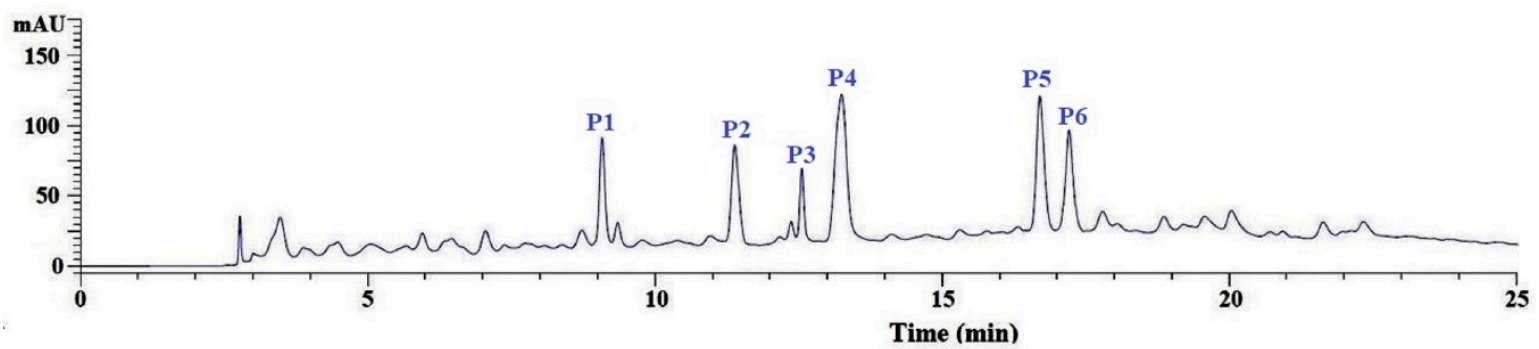

Figure 4. Reversed-phase high-performance liquid chromatography (RP-HPLC) chromatogram of GC-3 using a Zorbax, SB C-18 column $(4.6 \mathrm{~mm} \times 250 \mathrm{~mm})$.

\subsection{Molecular Structural Analysis}

The amino acid sequences of the six isolated APs (P1 to P6) were analyzed by a protein sequencer and identified as Val-Glu-Glu (VEE, P1), Trp-Met-Phe-Asp-Trp (WMFDW, P2), Asp-Ala-Gly-Pro-TyrGly-Pro-Ile (DAGPYGPI, P3), Trp-Met-Gly-Pro-Tyr (WMGPY, P4), Glu-Arg-Gly-Pro-Leu-Gly-Pro-His 
(ERGPLGPH, P5), and Glu-Met- Gly-Pro-Ala (EMGPA, P6), respectively (Table 1). In addition, the MWs of VEE (P1), WMFDW (P2), DAGPYGPI (P3), WMGPY (P4), ERGPLGPH (P5), and EMGPA (P6) were $375.39,783.90,788.85,652.79,861.95$, and 503.58 Da, respectively (Figure 5). Those MW data of the six isolated APs (P1 to P6) agreed well with their theoretical masses (Table 1).

Table 1. Retention time (RT), molecular mass (Da), and amino acid sequences of six isolated antioxidant peptides (APs) (P1 to P6) from the protein hydrolysate of skipjack tuna heads.

\begin{tabular}{cccc}
\hline No. & RT (min) & Theoretical Mass/Observed Mass (Da) & Amino Acid Sequence \\
\hline P1 & 9.05 & $375.37 / 375.39$ & VEE \\
P2 & 11.36 & $783.89 / 783.90$ & WMFDW \\
P3 & 12.63 & $788.84 / 788.85$ & DAGPYGPI \\
P4 & 13.25 & $652.76 / 652.79$ & WMGPY \\
P5 & 16.78 & $861.94 / 861.95$ & ERGPLGPH \\
P6 & 17.22 & $503.57 / 503.58$ & EMGPA \\
\hline
\end{tabular}
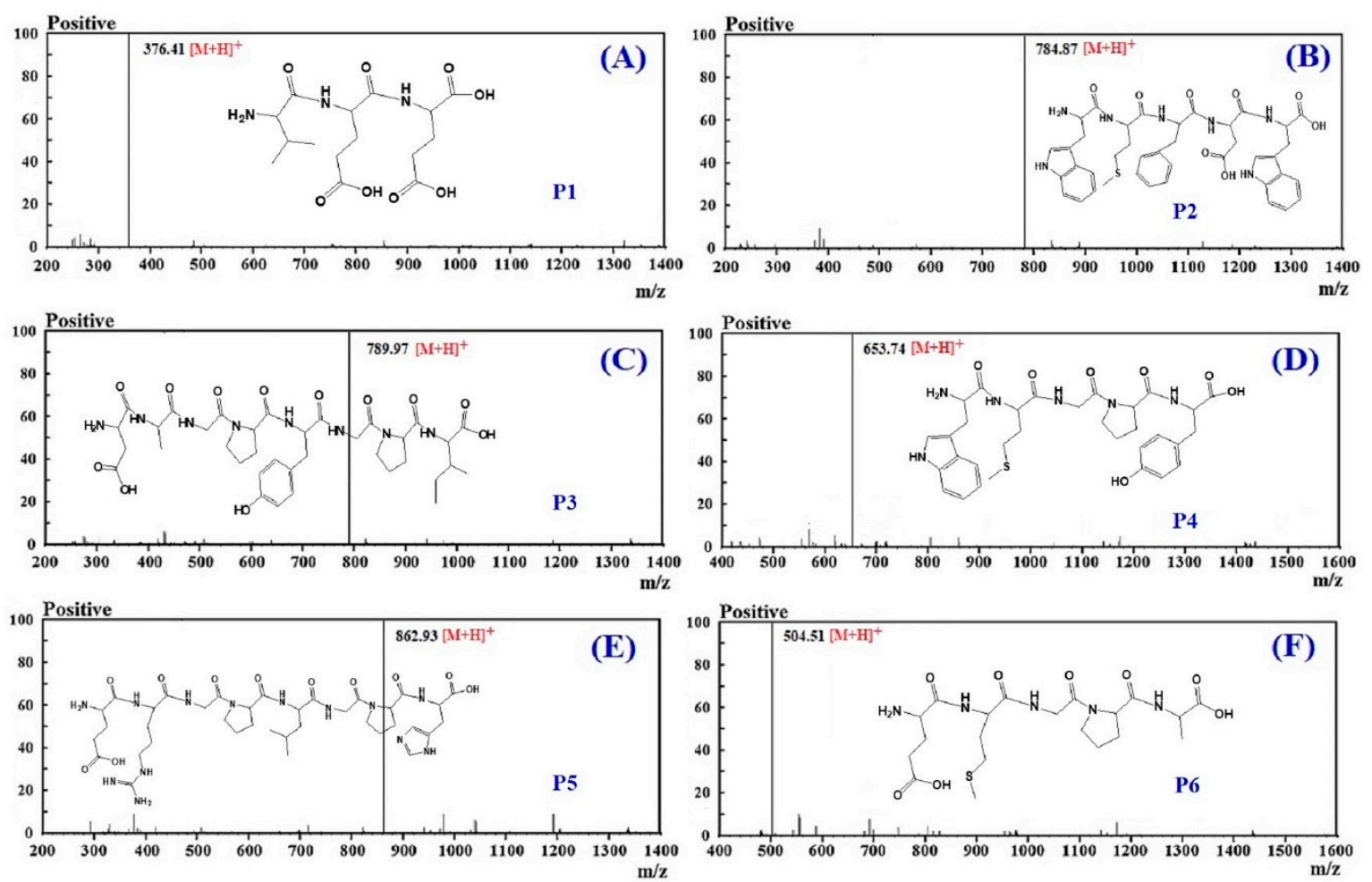

Figure 5. Mass spectrogram of P1 (A), P2 (B), P3 (C), P4 (D), P5 (E), and P6 (F) from the hydrolysate of skipjack tuna (K. pelamis) heads.

\subsection{Antioxidant Activity}

In the experiment, radical scavenging, reducing power and lipid peroxidation inhibiting assays were used to evaluate the activity of six isolated APs (P1 to P6) from the hydrolysate of skipjack tuna heads, and the experimental data were showed in Table 2 and Figures 6-8.

\subsubsection{Radical Scavenging Activity}

DPPH Radical Scavenging Activity

Figure 6A indicated that six isolated APs (P1 to P6) can positively influence the DPPH radical scavenging rates when the concentrations of APs ranged from 0.05 to $5.0 \mathrm{mg} / \mathrm{mL}$. Among six isolated APs, the EC 50 value of P2 $(0.31 \mathrm{mg} / \mathrm{mL})$, P4 $(0.33 \mathrm{mg} / \mathrm{mL})$, P5 $(0.93 \mathrm{mg} / \mathrm{mL}))$, and P6 $(0.46 \mathrm{mg} / \mathrm{mL})$ was less than $1.0 \mathrm{mg} / \mathrm{mL}$ (Table 2). Moreover, the $\mathrm{EC}_{50}$ value of P2 and P4 did not show a significant difference 
with the positive control of GSH ( $p>0.05)$. The $\mathrm{EC}_{50}$ values of P2 and P4 were lower than those of most APs from protein hydrolysates of aquatics and their processing by-products, such as blue mussel (M. edulis) (YPPAK: $2.62 \mathrm{mg} / \mathrm{mL}$ ) [31], skate cartilages (FIMGPY: $2.60 \mathrm{mg} / \mathrm{mL}$; GPAGDY: $3.48 \mathrm{mg} / \mathrm{mL}$; IVAGPQ: $3.93 \mathrm{mg} / \mathrm{mL}$ ) [3], the pectoral fin of salmon (TTANIEDRR: $2.50 \mathrm{mg} / \mathrm{mL}$ ) [36], spanish mackerel skins (PFGPD: $0.80 \mathrm{mg} / \mathrm{mL}$; PYGAKG: $3.02 \mathrm{mg} / \mathrm{mL}$; YGPM: $0.72 \mathrm{mg} / \mathrm{mL}$ ) [37], Tergillarca granosa muscle (MDLFTE: $0.53 \mathrm{mg} / \mathrm{mL}$; WPPD: $0.36 \mathrm{mg} / \mathrm{mL}$ ) [34], miiuy croaker swim bladders (FPYLRH: $0.78 \mathrm{mg} / \mathrm{mL}$; GIEWA: $0.78 \mathrm{mg} / \mathrm{mL}$ ) [8], croceine croaker muscle (YLMSR: $1.35 \mathrm{mg} / \mathrm{mL}$ ) [38], and loach (PSYV: $17.0 \mathrm{mg} / \mathrm{mL}$ ) [39]. Nevertheless, the $\mathrm{EC}_{50}$ values of P2 and P4 were greater than those of APs from the hydrolysates of grass carp skin (HFGBPFH: $0.20 \mathrm{mg} / \mathrm{mL}$ ) [40], bluefin leatherjacket skin (FIGP: $0.12 \mathrm{mg} / \mathrm{mL}$ ) [12], and skate muscle (NWDMEKIWD: $0.29 \mathrm{mg} / \mathrm{mL}$ ) [41]. Then, six isolated APs (P1 to P6), especially P2 and P4, have a strong ability to inhibit the DPPH radical reaction through donating hydrogens or scavenging free radicals.

Table 2. $\mathrm{EC}_{50}$ vales of six isolated APs (P1 to P6) on the DPPH radical, hydroxyl radical and superoxide anion radical.

\begin{tabular}{cccc}
\hline \multirow{2}{*}{ No. } & \multicolumn{3}{c}{ EC $_{\mathbf{5 0}}(\mathbf{m g} / \mathbf{m L})$} \\
\cline { 2 - 4 } & DPPH Radical & Hydroxyl Radical & Superoxide Anion Radical \\
\hline P1 & $3.76 \pm 0.16^{\mathrm{a}}$ & $2.43 \pm 0.11^{\mathrm{a}}$ & $1.79 \pm 0.11^{\mathrm{a}}$ \\
P2 & $0.31 \pm 0.02^{\mathrm{b}}$ & $0.30 \pm 0.03^{\mathrm{b}}$ & $0.56 \pm 0.04^{\mathrm{b}}$ \\
P3 & $1.33 \pm 0.09^{\mathrm{c}}$ & $1.71 \pm 0.06^{\mathrm{c}}$ & $1.51 \pm 0.11^{\mathrm{c}}$ \\
P4 & $0.33 \pm 0.02^{\mathrm{b}}$ & $0.43 \pm 0.02^{\mathrm{d}}$ & $0.38 \pm 0.03^{\mathrm{d}}$ \\
P5 & $0.93 \pm 0.04^{\mathrm{d}}$ & $0.81 \pm 0.04^{\mathrm{e}}$ & $3.04 \pm 0.18^{\mathrm{e}}$ \\
P6 & $0.46 \pm 0.04^{\mathrm{e}}$ & $0.52 \pm 0.04^{\mathrm{d}}$ & $0.71 \pm 0.04^{\mathrm{b}}$ \\
GSH & $0.22 \pm 0.01^{\mathrm{b}}$ & $0.12 \pm 0.01^{\mathrm{f}}$ & $0.09 \pm 0.01^{\mathrm{f}}$ \\
\hline
\end{tabular}

The data are presented as the mean $\pm \mathrm{SD}(n=3) .{ }^{\mathrm{a}-\mathrm{f}}$ Values with the same letters of different samples indicate no significant difference $(p>0.05)$.

\section{Hydroxyl Radical Scavenging Activity}

Figure 6B revealed that P1, P2, P3, P4, P5, and P6 can concentration-dependently scavenge hydroxyl radicals with $\mathrm{EC}_{50}$ values of $2.43,0.30,1.71,0.43,0.81$, and $0.52 \mathrm{mg} / \mathrm{mL}$, respectively (Table 2). $\mathrm{P} 2$ revealed the highest radical scavenging ability among six isolated APs, but its $\mathrm{EC}_{50}$ value was none the less significantly less than that of GSH $(0.12 \mathrm{mg} / \mathrm{mL})(p<0.05)$. All the more important, the $\mathrm{EC}_{50}$ value of P2 was lower than those of most APs from hydrolysates of the muscle of croceine croaker (YLMSR: $0.35 \mathrm{mg} / \mathrm{mL}$ ) [38], miiuy croaker swim bladders (GFYAA: $2.35 \mathrm{mg} / \mathrm{mL}$; FSGLR: $2.45 \mathrm{mg} / \mathrm{mL}$ ) [8], weatherfish loach (PSYV: $2.64 \mathrm{mg} / \mathrm{mL}$ ) [39], conger eel (LGLNGDDVN: $0.69 \mathrm{mg} / \mathrm{mL}$ ) [42], bluefin leatherjacket (GPP: $2.36 \mathrm{mg} / \mathrm{mL}$ ) [6], giant squid (NADFGLNGLEGLA: $0.61 \mathrm{mg} / \mathrm{mL}$ ) [43], hairtail muscle (IYG: $2.50 \mathrm{mg} / \mathrm{mL}$; AKG: $2.38 \mathrm{mg} / \mathrm{mL}$; KA: $1.74 \mathrm{mg} / \mathrm{mL}$ ) [44], and grass carp skin (PYSFK: $2.28 \mathrm{mg} / \mathrm{mL}$; VGGRP: $2.06 \mathrm{mg} / \mathrm{mL}$ ) [40]. Nevertheless, the EC $_{50}$ value of P2 was still greater than those of APs from bluefin leatherjacket skin (FIGP: $0.07 \mathrm{mg} / \mathrm{mL}$ ) [12], Sphyrna lewini muscle (SAP: $0.17 \mathrm{mg} / \mathrm{mL}$; PYFNA: $0.24 \mathrm{mg} / \mathrm{mL}$ ) [32,33], and monkfish muscle (EWPAQ: $0.27 \mathrm{mg} / \mathrm{mL}$; FLHRP: $0.11 \mathrm{mg} / \mathrm{mL}$; LMGQW: $0.04 \mathrm{mg} / \mathrm{mL}$ ) [45]. In the body, hydroxyl radicals can give rise to the process of oxidative stress to unselectively attack and oxidize biomacromolecules, and further cause some chronic diseases. The results indicated that P2 can serve as a hydroxyl radical eliminator to eliminate its injury in biological systems.

\section{Superoxide Anion Radical Scavenging Assay}

Figure 6C indicated that the scavenging ability of six isolated APs (P1 to P6) on the superoxide anion radical enhanced gradually following the increase in peptide content within the range of 0.05-5.0 mg/mL. The $\mathrm{EC}_{50}$ value of $\mathrm{P} 4$ was $0.38 \mathrm{mg} / \mathrm{mL}$, which was significantly less than those of other five isolated APs $\left(\mathrm{EC}_{50}\right.$ values of $1.79,0.56,1.51,3.04$, and $0.71 \mathrm{mg} / \mathrm{mL}$ for P1, P2, P3, P5, 
and P6, respectively), but significantly greater than that of GSH $(0.09 \mathrm{mg} / \mathrm{mL})(p<0.05)$. What is more, the $\mathrm{EC}_{50}$ value of $\mathrm{P} 4$ was lower than those of APs from hydrolysates of muscle of monkfish (EWPAQ: $0.62 \mathrm{mg} / \mathrm{mL}$ ) [45], skate cartilage (FIMGPY: $1.61 \mathrm{mg} / \mathrm{mL}$; GPAGDY: $1.66 \mathrm{mg} / \mathrm{mL}$; IVAGPQ: $1.82 \mathrm{mg} / \mathrm{mL}$ ) [3], hairtail muscle $\left(\mathrm{EC}_{50}\right.$ values of $1.34,2.54$, and $2.08 \mathrm{mg} / \mathrm{mL}$ for IYG, AKG, and $\mathrm{KA}$, respectively) [44], swim bladders of miiuy croaker ( $\mathrm{EC}_{50}$ values of $3.35,1.92,0.87,3.03$, and $3.04 \mathrm{mg} / \mathrm{mL}$ for FSGLR, FYKWP, GFEPY, GFYAA, and FTGMD, respectively) [8], Tergillarca granosa muscle (MDLFTE: $0.75 \mathrm{mg} / \mathrm{mL}$; WPPD $0.46 \mathrm{mg} / \mathrm{mL}$ ) [13], and croceine croaker muscle (MILMR: $0.993 \mathrm{mg} / \mathrm{mL}$ ) [38]. However, the $\mathrm{EC}_{50}$ values of P4 were higher than those of APs from protein hydrolysates of round scad (HEKVC: $0.235 \mathrm{mg} / \mathrm{mL}$; HDHPVC: $0.265 \mathrm{mg} / \mathrm{mL}$ ) [46], bluefin leatherjacket skin (FIGP: $0.311 \mathrm{mg} / \mathrm{mL}$ ) [12], red stingray cartilages (IEPH: $0.17 \mathrm{mg} / \mathrm{mL}$; IEEEQ: $0.16 \mathrm{mg} / \mathrm{mL}$ ) [37], and muscle of monkfish (FLHRP: $0.101 \mathrm{mg} / \mathrm{mL}$ ) [45]. As a major product of the primary oxidase sources of ROS in organisms, superoxide anion radicals can damage the carbonyl compounds and initiate lipid peroxidation when they convert to the highly reactive hydroxyl radical. In addition, the potential damage of superoxide anion radicals can be scavenged by SOD. Therefore, six isolated APs (P1 to P6), especially $\mathrm{P} 4$, can act as the radical eliminators to eliminate the radical damage along with SOD.
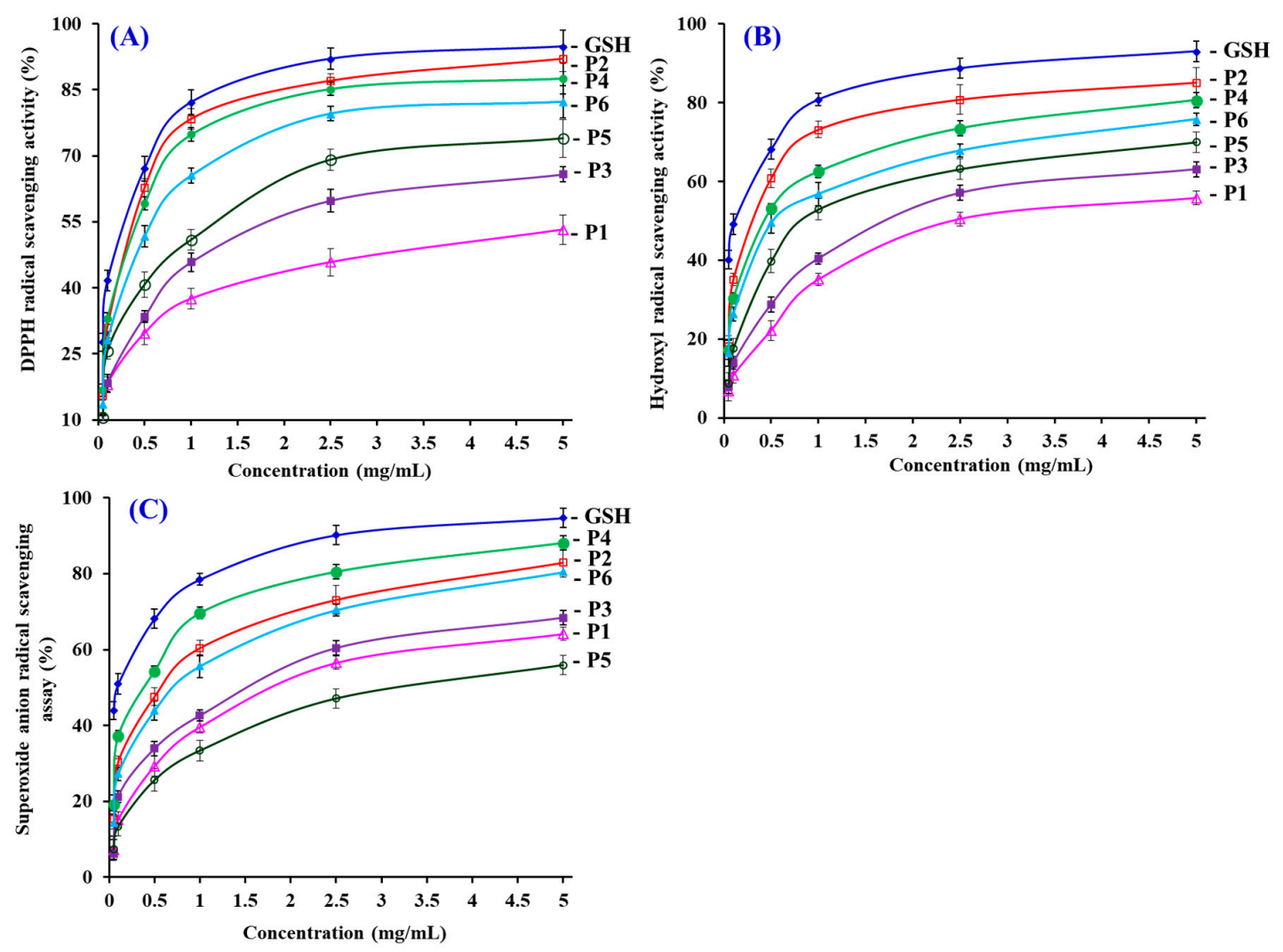

Figure 6. DPPH radical (A), hydroxyl radical (B), and superoxide anion radical (C) scavenging activities of six isolated APs (P1 to P6) from the hydrolysate of skipjack tuna (K. pelamis) heads. The data are presented as the mean $\pm \mathrm{SD}(n=3)$.

\subsubsection{Reducing power}

Figure 7 shows that six isolated APs (P1 to P6) showed concentration-dependent reducing power when AP concentrations were increased from 0.05 to $2.0 \mathrm{mg} / \mathrm{mL}$. P2 have the highest reducing capacity on converting $\mathrm{Fe}^{3+} /$ ferricyanide complex into the ferrous form among the six APs. However, the reducing power of the APs was lower than that of the positive control of GPS. Reducing power is referred to as the ability of antioxidants to donate electrons and hydrogen in reduction reactions in organisms. The reducing capacity of an AP is considered as a key indicator of its potential antioxidant activity $[17,29]$. The present results suggested that $\mathrm{P} 4$ can serve as primary and secondary 
antioxidants to decrease the oxidized intermediates of lipid peroxidation reactions through acting as an electron donor.

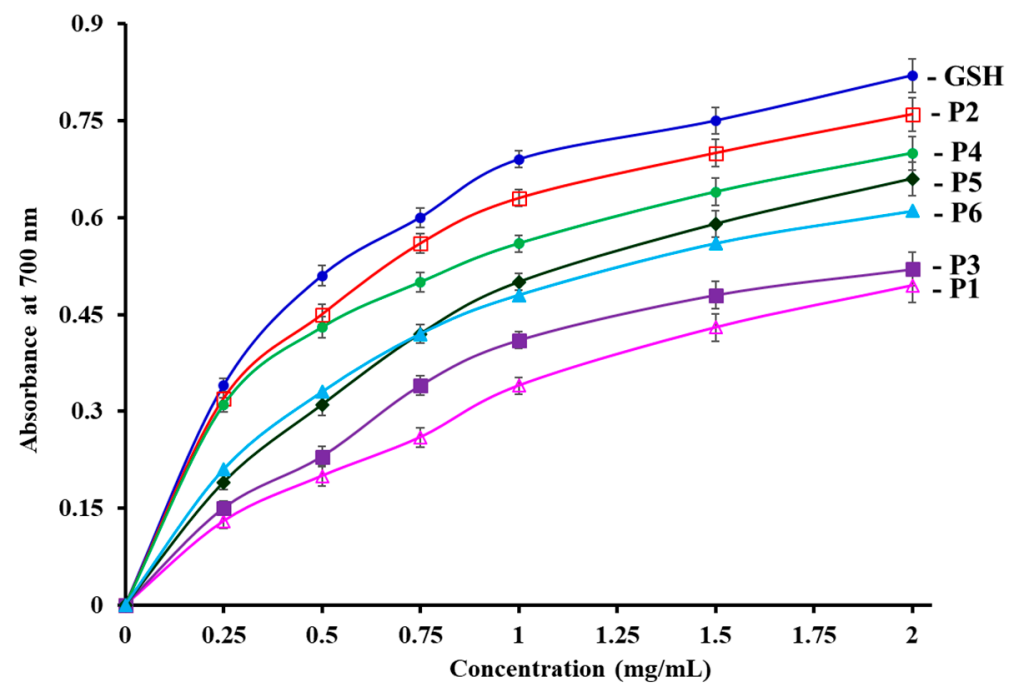

Figure 7. The reducing power of six isolated APs (P1 to P6) from the hydrolysate of skipjack tuna (K. pelamis) heads. The data are presented as the mean $\pm \mathrm{SD}(n=3)$.

\subsubsection{Lipid Peroxidation Inhibition Assay}

Using the linoleic acid model system, the lipid peroxidation inhibition abilities of six isolated APs (P1 to P6) were determined and the lower absorbance at $700 \mathrm{~nm}$ illustrates higher antioxidant activity [32]. As showed in Figure 8, the absorbance value of the blank control was significantly higher than those of the six isolated APs (P1 to P6) and the positive control of GSH groups, which indicated that six isolated APs (P1 to P6) and GSH can inhibit the peroxidation of linoleic acid during 7 days incubation. In addition, the absorbance values of $\mathrm{P} 2$ and $\mathrm{P} 4$ groups was lower than those of the other four APs (P1, P3, P5 and P6). The results indicated that P2 and P4 could serve as the primary and secondary antioxidants to inhibit lipid oxidation in food products.

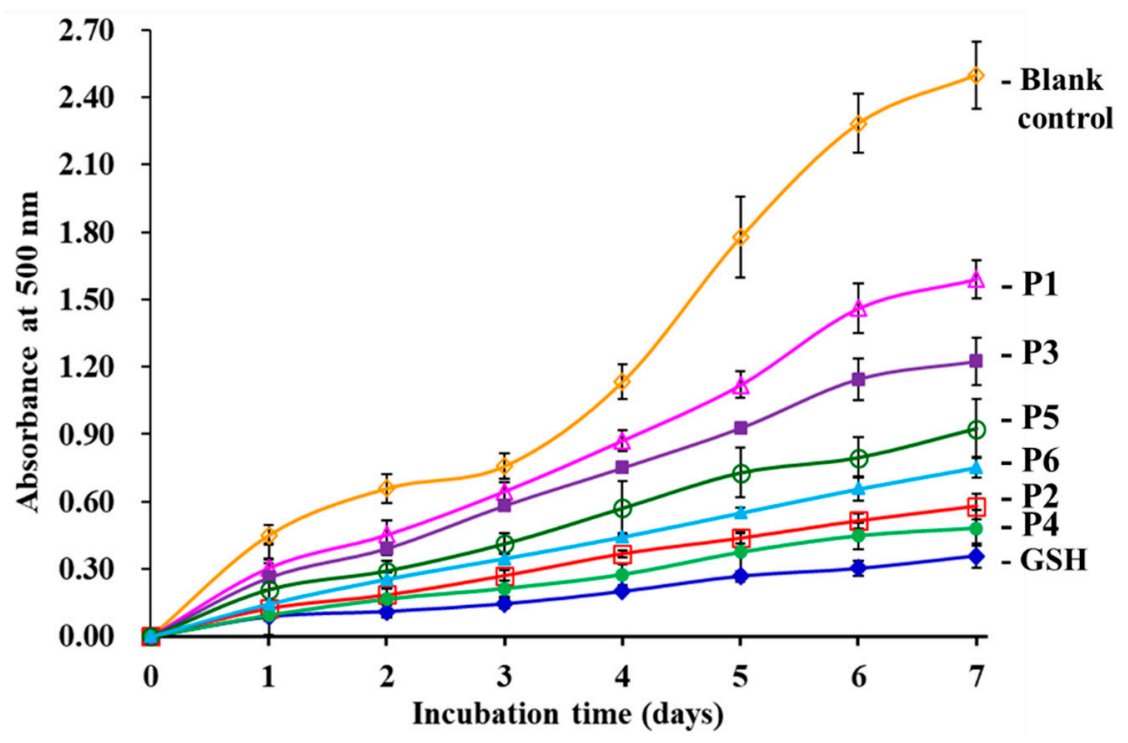

Figure 8. Lipid peroxidation inhibition capability of six isolated APs (P1 to P6) from the hydrolysate of skipjack tuna (K. pelamis) heads. The data are presented as the mean $\pm \operatorname{SD}(n=3)$. 


\subsection{Effects of Thermal and $p H$ Treatments on the Stability of $P 2, P 4$ and $P 6$}

Figure 9A indicated that the scavenging activity of P2, P4 and P6 on hydroxyl radicals (presented as $\mathrm{EC}_{50}$ value) has the same varying tendency. Heat treatments can greatly affect their activity and the $\mathrm{EC}_{50}$ values of $\mathrm{P} 2, \mathrm{P} 4$, or $\mathrm{P} 6$ treated at 20 and $40{ }^{\circ} \mathrm{C}$ were significantly $(p>0.05)$ different from those treated at 60,80 , and $100{ }^{\circ} \mathrm{C}$, respectively $(p<0.05)$. On the other hand, there was no significant difference in their $\mathrm{EC}_{50}$ values on hydroxyl radicals when $\mathrm{P} 2$, $\mathrm{P} 4$, or $\mathrm{P} 6$ were disposed at 20 and $40{ }^{\circ} \mathrm{C}$ for $0.5 \mathrm{~h}$, respectively $(p>0.05)$.
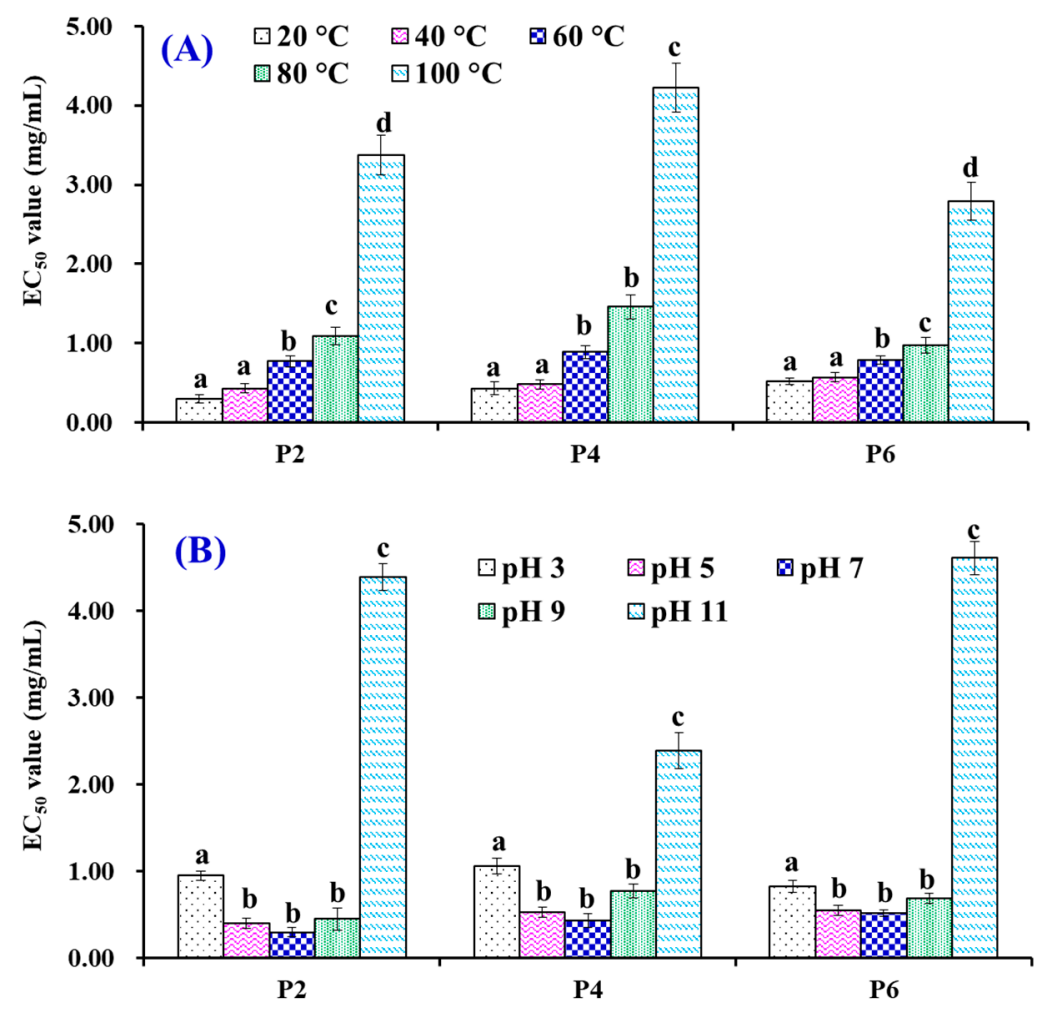

Figure 9. $\mathrm{EC}_{50}$ values of $\mathrm{P} 2, \mathrm{P} 4$ and $\mathrm{P} 6$ on hydroxyl radical scavenging activity when treated at different temperatures $(\mathbf{A})$ and $\mathrm{pH}$ values $(\mathbf{B})$. The data are expressed as the mean $\pm \mathrm{SD}(n=3) .{ }^{\text {a-d }}$ Values with same letters of same sample indicate no significant difference $(p>0.05)$.

Figure 9B shows the influences of acid and alkali treatments on P2, P4 and P6. The results indicated that the $\mathrm{EC}_{50}$ values of $\mathrm{P} 2$, $\mathrm{P} 4$, or $\mathrm{P} 6$ showed no significant difference when the $\mathrm{pH}$ value ranged from 5 to 9, but they were significantly different from the $\mathrm{EC}_{50}$ values of $\mathrm{P} 2$, $\mathrm{P} 4$, or $\mathrm{P} 6$ treated at $\mathrm{pH} 3$ or $\mathrm{pH}$ 11. In addition, the alkaline treatment had a stronger effect on P2 and P6 compared with P4.

\section{Discussion}

Proteins in seafoods and their by-products have a high structural diversity and represent a massive resource for the mining of bioactive peptides [1]. Bioactive peptides are released from the sequence of proteins by different hydrolysis methods, such as solvent extraction, microbial fermentation, enzymatic hydrolysis and chemical treatment [5]. Nevertheless, the proteolytic hydrolysis process is the popular method in health care food industries to avoid toxic chemicals or residual organic solvents in the final products. In addition, the specificity and parameters of the proteases significantly affect the MW and amino acid composition of bioactive peptides [47-49]. In some cases, specific enzyme combinations are used to enhance the DH of protein and prepare hydrolysates enriched with low MW APs $[44,48,50]$.

The structural activity specialties can provide guides to speculate the activity of isolated APs. The amino acid composition and sequence, MW or molecular size, and spatial structures are deemed 
to have a vital role in the activity of APs. In general, APs with a low MW have more opportunities to interact with target molecules to terminate free radical reactions and prevent unsaturated lipid peroxidation [44]. The conclusion was confirmed by the literature that the antioxidant capacities of protein hydrolysates or APs were inversely related to the logarithm of their average MW [29,35]. In addition, small APs have a high likelihood to exploit new drugs because they easily pass through the blood-brain barrier to cause effects in human bodies [32]. The six isolated APs (P1 to P6) are tripeptides to octapeptides with MWs varying from 375.39 to $861.95 \mathrm{Da}$ (Table 1), which shows that they have a high chance of interacting with ROS to prevent lipid peroxidation.

Previous literature indicated that the kinds of amino acids in the APs were regarded as key factors for their activity [5]. The hydrophobic groups of hydrophobic amino acid residues such as Pro, Met, Ala, Leu, and Ile, can highly react with hydrophobic polyunsaturated fatty acids (PUFAs) to inhibit lipid peroxidation in lipid-rich foods $[6,8]$. Wu et al. confirmed that the inhibiting ability of Pro-Met-Arg-Gly-Gly-Gly-Gly-Tyr-His-Tyr (PMRGGGGYHY) on free-radical chain reactions was attribute to Met residue because it could serve as a reactive site for formatting a sulfoxide structure to scavenge oxidants [51]. The pyrrolidine ring of the Pro residue can increase the antioxidant ability of Pro-His-His (PHH), Leu-Asp-Glu-Pro-Asp-Pro-Leu (LDEPDPL), Gly-Pro-Gly-Gly-Phe-Ile (GPGGFI), and Phe-Ile-Gly-Pro (FIGP), and to scavenge ROS due to its low ionization potential [52,53]. Zhao et al. [8] and Yang et al. [44] reported that the Ala residues contribute to the ability of Gly-Ile-Glu-Trp-Ala (GIEWA) and Ala-Lys-Gly (AKG) on radical-scavenging and lipid peroxidation inhibition. Moreover, the aromatic groups of Trp, Phe, and Tyr residues can provide protons to stabilize electron-deficient radicals [54,55]. Guo et al. reported that the sequence of APs with Trp residues (Trp-Asn-Glu-His and His-Glu-Trp) and Tyr residues (Arg-Tyr, Lys-Tyr, Tyr-Asp, Tyr-Tyr, Arg-Tyr-Asn, Tyr-Asp-Tyr, Tyr-Glu-Gly, and Tyr-Glu-Glu-Asn) showed high antioxidative ability [54]. The Phe residue in KHNRGDEF can serve as a radical scavenger through providing protons to quench unpaired radicals [55]. In consequence, hydrophobic/aromatic amino acid residues in WMFDW (Trp, Met, and Phe), WMGPY (Trp, Met, and Pro), and EMGPA (Met, Pro and Ala) are vital factors for their activity.

The carboxyl and amino groups in polar amino acid residues are important for the hydroxyl radical scavenging and metal ion chelating capacities of APs [8,30]. Acidic amino acid residues of Asp and Glu were reported to have great influence on the antioxidant activities of Asn-Tyr-Asp-Gly-Ser-Thr-Asp-TyrGly-Ile-Leu-Gln-Ile-Asn-Ser-Arg and Leu-Asp-Glu-Pro-Asp-Pro-Leu-Ile [56,57]. In addition, Gly residue can keep the high flexibleness of the polypeptide skeleton and its single hydrogen atom can be donated to neutralize ROS $[5,31,58]$. Therefore, polar amino acids, including the Asp residue in WMFDW, Gly residue in WMGPY, and Gly and Glu residues in EMGPA, should play a critical role in their scavenging activities of hydroxyl radicals.

Heating and acid-base treatments are common processing methods in the food industry. APs with heat-resistant properties are beneficial to increase the quality guarantee period of food products when they can retain all or major activity after heating treatment, and APs can be used in more kinds of liquid products if they keep their bioactivity in a wide range of $\mathrm{pH}$ values [19]. Therefore, the thermal and $\mathrm{pH}$ stability of APs are key properties for designing their specific parameters for application in food products $[13,36,59]$. Wong et al. prepared two antioxidant hexapeptides (Trp-Ala-Phe-Ala-Pro-Ala and Met-Tyr-Pro-Gly-Leu-Ala) from the hydrolysate of blue-spotted stingray and confirmed that the two hexapeptides had excellent stability because no significant difference was found when they were treated at $25-100^{\circ} \mathrm{C}$ or at $\mathrm{pH}$ values of $3-11(p>0.05)$ [19]. In contrast, Ala-Thr-Ser-His-His from the hydrolysate of sandfish incubated at $50-90^{\circ} \mathrm{C}$ reduced its partial DPPH radical scavenging activity. In addition, ATSHH absorbed moderate losses of activity when it was treated at $\mathrm{pH} 10-12$ or $\mathrm{pH} 2$. Yang et al. released homologous conclusions that Met-Asp-Leu-Phe-Thr-Glu and Trp-Pro-Pro-Asp from protein hydrolysates of Tergillarca granosa were not appropriate for high-temperature processing $\left(>80{ }^{\circ} \mathrm{C}\right)$ and alkaline conditions $(\mathrm{pH}>9.0)$ in food products [13]. The present results indicate that P2 (WMFDW), P4 (WMGPY), and P6 (EMGPA) have similar thermal and pH stability with ATSHH, 
MDLFTE and WPPD, because they can significantly decrease antioxidant activity when they are treated under high temperature $\left(80\right.$, and $\left.100^{\circ} \mathrm{C}\right)$ and acid $(\mathrm{pH} 3)$ and alkali $(\mathrm{pH} 9)$ conditions.

\section{Conclusions}

In this experiment, skipjack tuna (K. pelamis) heads were hydrolyzed by in vitro GI digestion and six APs separated from the hydrolysate (KPH) were identified as VEE, WMFDW, DAGPYGPI, WMGPY, ERGPLGPH, and EMGPA, respectively. The six isolated APs, especially MDLFTE, WPPD, and EMGPA, exhibited high radical scavenging, reducing power, and lipid peroxidation inhibition capabilities. In addition, MDLFTE, WPPD, and EMGPA are unstable and can keep effective antioxidant activity when environmental temperatures are lower than $60{ }^{\circ} \mathrm{C}$ and $\mathrm{pH}$ values range from 5 to 9 . The investigation showed that the hydrolysates and APs from skipjack tuna (K. pelamis) heads can be served as antioxidant functional ingredients in health care products.

Author Contributions: C.-F.C. and B.W. conceived the experiments, contributed the reagents and materials, and wrote the paper. L.Z., G.-X.Z., Y.-T.Q. and Y.-Q.Z. performed the experiments and analyzed the data.

Funding: This work was funded by the National Natural Science Foundation of China (No. 81673349) and Zhejiang Province Public Technology Research Project (No. LGN18D060002).

Acknowledgments: We thank Zhao-Hui Zhang at Beijing agricultural biological testing center for his technical support on the isolation and identification of APs.

Conflicts of Interest: The authors declare no conflicts of interest.

\section{References}

1. Harnedy, P.A.; FitzGerald, R.J. Bioactive peptides from marine processing waste and shellfish: A review. J. Funct. Foods 2012, 4, 6-24. [CrossRef]

2. Du, Y.; Esfandi, R.; Willmore, W.G.; Tsopmo, A. Antioxidant activity of oat proteins derived peptides in stressed hepatic HepG2 cells. Antioxidants 2016, 5, 39. [CrossRef] [PubMed]

3. Pan, X.; Zhao, Y.Q.; Hu, F.Y.; Wang, B. Preparation and identification of antioxidant peptides from protein hydrolysate of skate (Raja porosa) cartilage. J. Funct. Foods 2016, 25, 220-230. [CrossRef]

4. Zhang, Q.; Tong, X.; Li, Y.; Wang, H.; Wang, Z.; Qi, B.; Sui, X.; Jiang, L. Purification and characterization of antioxidant peptides from alcalase-hydrolyzed soybean (Glycinemax L.) hydrolysate and their cytoprotective effects in human intestinal Caco-2 cells. J. Agric. Food Chem. 2019, 67, 5772-5781.

5. Sila, A.; Bougatef, A. Antioxidant peptides from marine by-products: Isolation, identification and application in food systems. A review. J. Funct. Foods 2016, 21, 10-26. [CrossRef]

6. Chi, C.F.; Wang, B.; Wang, Y.M.; Zhang, B.; Deng, S.G. Isolation and characterization of three antioxidant peptides from protein hydrolysate of bluefin leatherjacket (Navodon septentrionalis) heads. J. Funct. Foods 2015, 12, 1-10. [CrossRef]

7. Agyei, D.; Ongkudon, C.M.; Wei, C.Y.; Chan, A.S.; Danquahd, M.K. Bioprocess challenges to the isolation and purification of bioactive peptides. Food Bioprod. Process. 2016, 98, 244-256. [CrossRef]

8. Zhao, W.H.; Luo, Q.B.; Pan, X.; Chi, C.F.; Sun, K.L.; Wang, B. Preparation, identification, and activity evaluation of ten antioxidant peptides from protein hydrolysate of swim bladders of miiuy croaker (Miichthys miiuy). J. Funct. Foods 2018, 47, 503-511. [CrossRef]

9. Xu, S.; Shen, Y.; Li, Y. Antioxidant activities of sorghum kafirin alcalase hydrolysates and membrane/gel filtrated fractions. Antioxidants 2019, 8, 131. [CrossRef]

10. Yang, X.R.; Zhao, Y.Q.; Qiu, Y.T.; Chi, C.F.; Wang, B. Preparation and characterization of gelatin and antioxidant peptides from gelatin hydrolysate of Skipjack tuna (Katsuwonus pelamis) bone stimulated by in vitro gastrointestinal digestion. Mar. Drugs 2019, 17, 78. [CrossRef]

11. Kitts, D.D.; Weiler, K. Bioactive Proteins and Peptides from Food Sources. Applications of bioprocesses used in isolation and recovery. Curr. Pharm. Design 2003, 9, 1309-1323. [CrossRef] [PubMed]

12. Chi, C.F.; Wang, B.; Hu, F.Y.; Wang, Y.M.; Zhang, B.; Deng, S.G.; Wu, C.W. Purification and identification of three novel antioxidant peptides from protein hydrolysate of bluefin leatherjacket (Navodon septentrionalis) skin. Food Res. Int. 2015, 73, 124-129. [CrossRef] 
13. Yang, X.R.; Zhang, L.; Zhao, Y.Q.; Chi, C.F.; Wang, B. Purification and characterization of antioxidant peptides derived from protein hydrolysate of the marine bivalve mollusk Tergillarca granosa. Mar. Drugs 2019, 17, 251. [CrossRef]

14. Bougatef, A.; Nedjar-Arroume, N.; Manni, L.; Ravallec, R.; Barkia, A.; Guillochon, D.; Nasri, M. Purification and identification of novel antioxidant peptides from enzymatic hydrolysates of sardinelle (Sardinella aurita) by-products proteins. Food Chem. 2010, 118, 559-565. [CrossRef]

15. Ktari, N.; Fakhfakh, N.; Balti, R.; Ben Khaled, H.; Nasri, M.; Bougatef, A. Effect of degree of hydrolysis and protease type on the antioxidant activity of protein hydrolysates from cuttlefish (Sepia officinalis) by-products. J. Aquat. Food Prod. Technol. 2013, 22, 436-448. [CrossRef]

16. Silva, J.F.X.; Ribeiro, K.; Silva, J.F.; Cahú, T.B.; Bezerra, R.S. Utilization of tilapia processing waste for the production of fish protein hydrolysate. Anim. Feed Sci. Tech. 2014, 196, 96-106. [CrossRef]

17. He, Y.; Pan, X.; Chi, C.F.; Sun, K.L.; Wang, B. Ten new pentapeptides from protein hydrolysate of miiuy croaker (Miichthys miiuy) muscle: Preparation, identification, and antioxidant activity evaluation. LWT-Food Sci. Technol. 2019, 105, 1-8. [CrossRef]

18. Venkatesan, J.; Anil, S.; Kim, S.K.; Shim, M.S. Marine fish proteins and peptides for cosmeceuticals: A review. Mar. Drugs 2017, 15, 143. [CrossRef]

19. Wong, F.C.; Xiao, J.; Ong, M.G.-L.; Pang, M.J.; Wong, S.J.; The, L.K.; Chai, T.T. Identification and characterization of antioxidant peptides from hydrolysate of blue-spotted stingray and their stability against thermal, $\mathrm{pH}$ and simulated gastrointestinal digestion treatments. Food Chem. 2019, 271, 614-622. [CrossRef]

20. Zheng, L.; Yu, H.; Wei, H.; Xing, Q.; Zou, Y.; Zhou, Y.; Peng, J. Antioxidative peptides of hydrolysate prepared from fish skin gelatin using ginger protease activate antioxidant response element-mediated gene transcription in IPEC-J2 cells. J. Funct. Foods 2018, 51, 104-112. [CrossRef]

21. Xiao, Z.; Liang, P.; Chen, J.; Chen, MF.; Gong, F.; Li, C.; Zhou, C.; Hong, P.; Yang, P.; Qian, Z.J. A peptide YGDEY from tilapia gelatin hydrolysates inhibits UVB-mediated skin photoaging by regulating MMP-1 and MMP-9 expression in HaCaT cells. Photochem. Photobiol. 2019. [CrossRef] [PubMed]

22. Tao, J.; Zhao, Y.Q.; Chi, C.F.; Wang, B. Bioactive peptides from cartilage protein hydrolysate of spotless smoothhound and their antioxidant activity In vitro. Mar. Drugs 2018, 16, 100. [CrossRef] [PubMed]

23. Chi, C.F.; Hu, F.Y.; Wang, B.; Li, Z.R.; Luo, H.Y. Influence of amino acid compositions and peptide profiles on antioxidant capacities of two protein hydrolysates from skipjack tuna (Katsuwonus pelamis) dark muscle. Mar. Drugs 2015, 13, 2580-2601. [CrossRef]

24. Yu, D.; Chi, C.F.; Wang, B.; Ding, G.F.; Li, Z. Characterization of acid and pepsin soluble collagens from spine and skull of skipjack tuna (Katsuwonus pelamis). Chin. J. Nat. Med. 2014, 12, 712-720. [CrossRef]

25. Shyni, K.; Hema, G.S.; Ninan, G.; Mathew, S.; Joshy, C.G.; Lakshmanan, P.T. Isolation and characterization of gelatin from the skins of skipjack tuna (Katsuwonus pelamis), dog shark (Scoliodon sorrakowah), and rohu (Labeo rohita). Food Hydrocolloid. 2014, 39, 68-76. [CrossRef]

26. Bradford, M.M. A rapid and sensitive method for the quantification of microgram quantities of protein utilizing the principle of protein-dye binding. Anal. Biochem. 1976, 72, 248-254. [CrossRef]

27. Zhang, Y.; Duan, X.; Zhuang, Y. Purification and characterization of novel antioxidant peptides from enzymatic hydrolysates of tilapia (Oreochromis niloticus) skin gelatin. Peptides 2012, 38, 13-21. [CrossRef] [PubMed]

28. Ahn, C.B.; Kim, J.G.; Je, J.Y. Purification and antioxidant properties of octapeptide from salmon byproduct protein hydrolysate by gastrointestinal digestion. Food Chem. 2014, 147, 78-83. [CrossRef]

29. Li, Z.; Wang, B.; Chi, C.; Gong, Y.; Luo, H.; Ding, G. Influence of average molecular weight on antioxidant and functional properties of cartilage collagen hydrolysates from Sphyrna lewini, Dasyatis akjei and Raja porosa. Food Res. Int. 2013, 51, 283-293. [CrossRef]

30. Zhao, Y.Q.; Zhang, L.; Tao, J.; Chi, C.F.; Wang, B. Eight antihypertensive peptides from the protein hydrolysate of Antarctic krill (Euphausia superba): Isolation, identification, and activity evaluation on human umbilical vein endothelial cells (HUVECs). Food Res. Int. 2019, 121, 197-204. [CrossRef]

31. Wang, B.; Li, L.; Chi, C.F.; Ma, J.H.; Luo, H.Y.; Xu, Y.F. Purification and characterisation of a novel antioxidant peptide derived from blue mussel (Mytilus edulis) protein hydrolysate. Food Chem. 2013, 138, 1713-1719. [CrossRef] 
32. Wang, B.; Li, Z.R.; Chi, C.F.; Zhang, Q.H.; Luo, H.Y. Preparation and evaluation of antioxidant peptides from ethanol-soluble proteins hydrolysate of Sphyrna lewini muscle. Peptides 2012, 36, 240-250. [CrossRef]

33. Luo, H.Y.; Wang, B.; Li, Z.R.; Chi, C.F.; Zhang, Q.H.; He, G.Y. Preparation and evaluation of antioxidant peptide from papain hydrolysate of Sphyrna lewini muscle protein. LWT-Food Sci. Technol. 2013, 51, 281-288. [CrossRef]

34. Pan, X.Y.; Wang, Y.M.; Li, L.; Chi, C.F.; Wang, B. Four antioxidant peptides from protein hydrolysate of red stingray (Dasyatis akajei) cartilages: Isolation, identification, and in vitro activity evaluation. Mar. Drugs 2019, 17, 263. [CrossRef]

35. Chi, C.F.; Cao, Z.H.; Wang, B.; Hu, F.Y.; Li, Z.R.; Zhang, B. Antioxidant and functional properties of collagen hydrolysates from spanish mackerel skin as influenced by average molecular weight. Molecules 2014, 19, 11211-11230. [CrossRef]

36. Ahn, C.B.; Cho, Y.S.; Je, J.Y. Purification and anti-inflammatory action of tripeptide from salmon pectoral fin byproduct protein hydrolysate. Food Chem. 2015, 168, 151-156. [CrossRef] [PubMed]

37. Zhang, J.B.; Zhao, Y.Q.; Wang, Y.M.; Chi, C.F.; Wang, B. Eight collagen peptides from hydrolysate fraction of Spanish mackerel skins: Isolation, identification, and in vitro antioxidant activity evaluation. Mar. Drugs 2019, 17, 224. [CrossRef]

38. Chi, C.F.; Hu, F.Y.; Wang, B.; Ren, X.J.; Deng, S.G.; Wu, C.W. Purification and characterization of three antioxidant peptides from protein hydrolyzate of croceine croaker (Pseudosciaena crocea) muscle. Food Chem. 2015, 168, 662-667. [CrossRef]

39. You, L.; Zhao, M.; Regenstein, J.M.; Ren, J. Purification and identification of antioxidative peptides from loach (Misgurnus anguillicaudatus) protein hydrolysate by consecutive chromatography and electrospray ionizationmass spectrometry. Food Res. Int. 2010, 43, 1167-1173. [CrossRef]

40. Cai, L.; Wu, X.; Zhang, Y.; Li, X.; Ma, S.; Li, J. Purification and characterization of three antioxidant peptides from protein hydrolysate of grass carp (Ctenopharyngodon idella) skin. J. Funct. Foods 2015, 16, 234-242. [CrossRef]

41. Hu, F.Y.; Chi, C.F.; Wang, B.; Deng, S.G. Two novel antioxidant nonapeptides from protein hydrolysate of skate (Raja porosa) muscle. Mar. Drugs 2015, 13, 1993-2009. [CrossRef]

42. Ranathunga, S.; Rajapakse, N.; Kim, S.K. Purification and characterization of antioxidantative peptide derived from muscle of conger eel (Conger myriaster). Eur. Food Res. Technol. 2006, 222, 310-315. [CrossRef]

43. Rajapakse, N.; Mendis, E.; Byun, H.G.; Kim, S.K. Purification and in vitro antioxidative effects of giant squid muscle peptides on free radical-mediated oxidative systems. J. Nutr. Biochem. 2005, 9, 562-569. [CrossRef]

44. Yang, X.R.; Zhang, L.; Ding, D.G.; Chi, C.F.; Wang, B.; Huo, J.C. Preparation, identification, and activity evaluation of eight antioxidant peptides from protein hydrolysate of hairtail (Trichiurus japonicas) Muscle. Mar. Drugs 2019, 17, 23. [CrossRef]

45. Chi, C.F.; Wang, B.; Deng, Y.Y.; Wang, Y.M.; Deng, S.G.; Ma, J.Y. Isolation and characterization of three antioxidant pentapeptides from protein hydrolysate of monkfish (Lophius litulon) muscle. Food Res. Int. 2014, 55, 222-228. [CrossRef]

46. Jiang, H.; Tong, T.; Sun, J.; Xu, Y.; Zhao, Z.; Liao, D. Purification and characterization of antioxidative peptides from round scad (Decapterus maruadsi) muscle protein hydrolysate. Food Chem. 2014, 154, 158-163. [CrossRef]

47. Wang, B.; Wang, Y.M.; Chi, C.F.; Hu, F.Y.; Deng, S.G.; Ma, J.Y. Isolation and characterization of collagen and antioxidant collagen peptides from scales of croceine croaker (Pseudosciaena crocea). Mar. Drugs 2013, 11, 4641-4661. [CrossRef]

48. Lan, C.; Zhao, Y.Q.; Li, X.R.; Wang, B. High Fischer ratio oligopeptides determination from Antartic krill: Preparation, peptides profiles, and in vitro antioxidant activity. J. Food Biochem. 2019, 43, e12827. [CrossRef]

49. Chi, C.; Wang, B.; Li, Z.; Hu, F.; Luo, H. Influence of different hydrolysis processes on physicochemical, antioxidant and functional properties of collagen hydrolysates from cartilages of Sphyrna lewini, Dasyatis akjei and Raja porosa. J. Aquat. Food Prod. Technol. 2016, 25, 616-632. [CrossRef]

50. Feng, L.; Peng, F.; Wang, X.; Li, M.; Lei, H.; Xu, H. Identification and characterization of antioxidative peptides derived from simulated in vitro gastrointestinal digestion of walnut meal proteins. Food Res. Int. 2019, 116, 518-526. [CrossRef]

51. Wu, R.; Wu, C.; Liu, D.; Yang, X.; Huang, J.; Zhang, J.; Liao, B.; He, H. Antioxidant and antifreezing peptides from salmon collagen hydrolysate prepared by bacterial extracellular protease. Food Chem. 2018, 248, 346-352. [CrossRef] 
52. Saito, K.; Jin, D.H.; Ogawa, T.; Muramoto, K.; Hatakeyama, E.; Yasuhara, T.; Nokihara, K. Antioxidative properties of tripeptide libraries prepared by the combinatorial chemistry. J. Agric. Food Chem. 2003, 51, 3668-3674. [CrossRef]

53. Chang, O.K.; Ha, G.E.; Han, G.S.; Seol, K.H.; Kim, H.W.; Jeong, S.G.; Oh, M.H.; Park, B.Y.; Ham, J.S. Novel antioxidant peptide derived from the ultrafiltrate of ovomucin hydrolysate. J. Agric. Food Chem. 2013, 61, 7294-7300. [CrossRef]

54. Guo, H.; Kouzuma, Y.; Yonekura, M. Structures and properties of antioxidative peptides derived from royal jelly protein. Food Chem. 2009, 113, 238-245. [CrossRef]

55. Zhang, J.; Zhang, H.; Wang, L.; Guo, X.; Wang, X.; Yao, H. Antioxidant activities of the rice endosperm protein hydrolysate: Identification of the active peptide. Eur. Food Res. Technol. 2009, 229, 709-719. [CrossRef]

56. Memarpoor-Yazdi, M.; Asoodeh, A.; Chamani, J. A novel antioxidant and antimicrobial peptide from hen egg white lysozyme hydrolysates. J. Funct. Foods 2012, 4, 278-286. [CrossRef]

57. Zhu, C.Z.; Zhang, W.G.; Zhou, G.H.; Xu, X.L.; Kang, Z.L.; Yin, Y. Isolation and identification of antioxidant peptides from Jinhua ham. J. Agric. Food Chem. 2013, 61, 1265-1271. [CrossRef]

58. Li, X.R.; Chi, C.F.; Li, L.; Wang, B. Purification and identification of antioxidant peptides from protein hydrolysate of scalloped hammerhead (Sphyrna lewini) cartilage. Mar. Drugs 2017, 15, 61. [CrossRef]

59. Sun, L.; Zhang, Y.; Zhuang, Y. Antiphotoaging effect and purification of an antioxidant peptide from tilapia (Oreochromis niloticus) gelatin peptides. J. Funct. Foods 2013, 5, 154-162. [CrossRef]

(C) 2019 by the authors. Licensee MDPI, Basel, Switzerland. This article is an open access article distributed under the terms and conditions of the Creative Commons Attribution (CC BY) license (http://creativecommons.org/licenses/by/4.0/). 